\title{
A new predatory mite species of the genus Eustigmaeus (Stigmaeidae: Acari) from Punjab, Pakistan
}

\section{Bilal Saeed Khan, Muhammad Afzal*and Muhammad Hamid Bashir Assistant Professor, Deptt. of Agri. Entomology, University of Agricult., Faisalabad. Professor, University College of Agriculture, University of Sargodha, Sargodha* \\ Corresponding author: Dr. Bilal Saeed Khan (bsk_1703@yahoo.com) \\ Assistant Professor, Department of Agri. Entomology, University of Agriculture, Faisalabad. Cell: 009241 321-6646852: Fax: 0092419201083 \\ Muhammad Afzal E-mail: chafzal64@yahoo.com Cell: 0092413007634963 \\ Muhammad Hamid Bashir E-mail: hamiduaf@yahoo.com Cell: 0321-650959 \\ Total number of figures $=3$}

ABSTRACT

Mites belonging to the family stigmaeidae are known predators against the phytophagous mites and small soft-bodied insects. A survey was conducted to explore the predatory mite fauna of Punjab (Pakistan), a new predatory mite species of genus Eustigmaeus (Eustigmaeus hooriaae) was collected from Ameen Pur Bangla, 20 miles away north from district Faisalabad (Punjab) from Triticum aestivum (straw husk) by Bilal Saeed Khan and described here in this manuscript. Specimens were mounted on the glass slides with the help of Hoyer's medium. The drawings of different body parts were made with the help of an ocular grid in a high power microscope. These specimens were compared with the already described species. Ceremonial description, illustration of main body parts, host range and comparison remarks are also given. Eighteen (18) paratype females were collected. Twelve (12) from the same collection data and six (6) were collected from R.Y.Khan from leaf litter. All specimens were deposited in the Acarology Research Laboratory, Department of Agri. Entomology, University of Agriculture, Faisalabad, Pakistan.

Keywords: Stigmaeidae, Acari, Eustigmaeus, new species, predatory mite

\section{INTRODUCTION}

Eustigmaeus is one the largest genera of the stigmaeidae and contains more than eighty species. Eustigmaeus was initially a subgenus of the genus Stigmaeus, based on Stigmaeus kermesinus Koch, 1841 (Berlese 1910), but was later raised to the generic level (Oudemans, 1923 a). In the same year Oudemans (1923 b) erected the genus Ledermuelleria, but its definition was literally a repetition of that of Eustigmaeus. The problem had not been resolved in the following 50 years, until Wood (1973) re-examined two specimens named Stigmaeus kermesinus in Berlese's collection and found that species was congeneric with the species of genus Ledermuelleria, and synonymized Ledermuelleria with Eustigmaeus. Rimando \& Corpuz-Raros subdivided the genus into four genera, Eustigmaeus, Ledermuelleria, Wooderia and Chaudhria, a suggestion rejected by several specialists, such as Khanjani \& Ueckermann (2002) who preferred to retain the status quo, pending a 
revision of the entire genus. Summers (1957) and Summer \& Price (1961) redescribed 7 species, added 4 new species and a key was provided to the females of 11 species of this genus. Chaudhri (1965) described eleven new species of this genus. Wood (1966) described another 9 new species from Australia, thus raising the numbers to 31 in this genus. Gerson (1971 a) recorded 7 American species and 5 new species from Canada. Chaudhri (1974) described 4 new species from Punjab Pakistan to this genus. A new species of this genus has been described by the author in this manuscript from Punjab, Pakistan.

Diagnosis:

Body short, some or less robust gnathosoma, chelicerae not fussed together, dorsusm almost completely covered by 3 shields (Propodosoma, hysterosomal and suranal). Humeral shield large and prominent on ventral position. Major shield generally ornamented. 12-13 pairs of dorsal setae including 1 pair of humeral setae. Summers 1957 divided the species of this genus into 3 general groups.

(a) "Segnis" containing curved, plumili form dorsal setae and 1 pair genital setae.

(b) "Maculata" group contain robust species with clubbed or rod like dorsal setae, 2-3 pairs of genital setae and usually a very thick exoskeleton in which so called dimples appears.

(c) "Pectinata" group included the slightly smaller species having bushy setae, 3 pairs of genital setae.

Summers (1957) described that mite in Segnis group have only 1 pair of paragenital setae but new species collected by Chaudhri later on showed that there were also 2 pairs of para-genital setae.

\section{RESULTS AND DISCUSSION}

\section{Female: Dorsum: Eustigmaeus hooriaae n.sp.}

Body glubulate almost rounded $275 \mu \mathrm{m}$ long without gnathosoma, body width $225 \mu \mathrm{m}$, padipalp $115 \mu \mathrm{m}$. Chelicerae $75 \mu \mathrm{m}$, stylet $32 \mu \mathrm{m}$, padipalp 5-segmented, palpfemur with 2 hairy setae. Palpgenu with 1 long seta, tibial claw shorter in size than palptarsus, small accessory claw present with main tibial claw. Palptarsus 5 setae, triangular solenidion and a trifid sensillium. Dorsal shield with variable pattern of dimples, the base of dimples with neumerous tiny alveoli. Eyes 1 pair. Dorsal setae feathers like, midrib of each seta support an outstanding membrane or web (Fig. 1A).

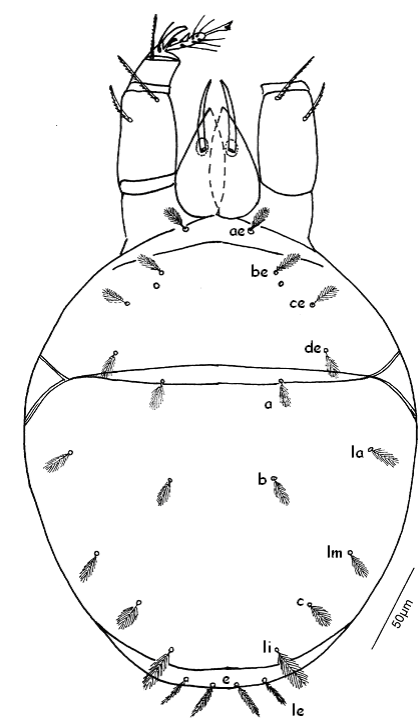

Fig. 1A. Eustigmaeus hooriaae n.sp. Dorsal Side 
Seta $l i 35 \mu \mathrm{m}$ amoung all other setae. Seta $a, b, c$ and $c e$ equal in length 20 $\mu \mathrm{m}$. Seta $l e$ and $e$ less bushy, not web like. Humeral seta he absent dorsally. 12 pairs of dorsal setae without humeral seta. Respective length of dorsal setae ae 17, be 20, ce 20, de 18, a 20, b 20, c 20, la 22, lm 22, li 35, le 17, e 22. The respective distances between ae-ae 37, be-be 80, ce-ce 137, de-de 176, a-a 62, b-b 55, c-c 16, c-li 32, a-b 52, $b$-c 70, la-lm 59 .

\section{Venter:}

Ventral gnothosoma provided with 3 pairs of setae, ventral idiosoma bear 4 pairs of setae having the same length. Sternal propodosomal area provided with rectangular dimples/patches. Sternal shield provided with reticulations clearly visible. Genital shield having 2 pairs of paragenital seta. 4 pairs of anogenital smooth setae with striations. Humeral seta present ventrally just above the humeral area, humeral shield ventrally striated (Fig. 1B).

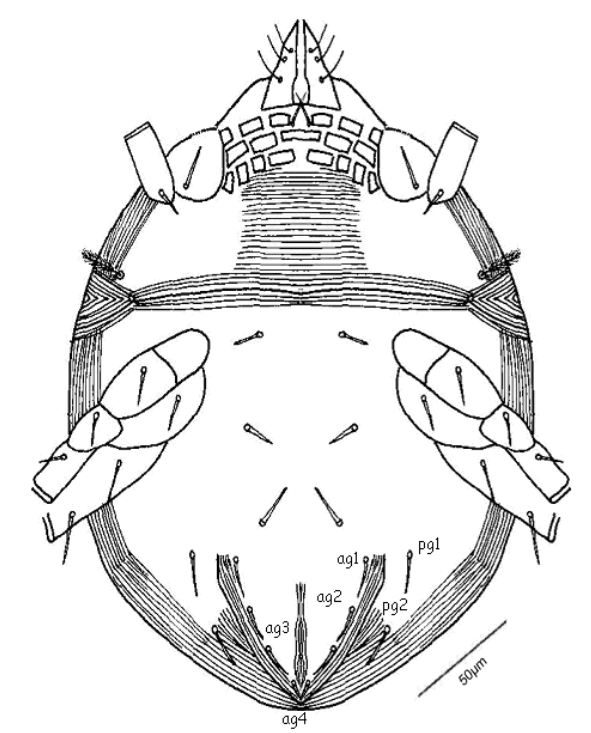

\section{Legs:}

Fig. 1 B. Eustigmaeus hooriaae n.sp. Ventral Side

Setae and sensilla on leg I-IV present. Chaetotaxy on leg I-IV (Fig. 1C) as follows: coxae 1-1-2-1; trochanters 1-1-2-1; femora 4-4-4-2; genua 3-3-1-2; tibiae 43-4-4; tarsi 8-9-6-5.

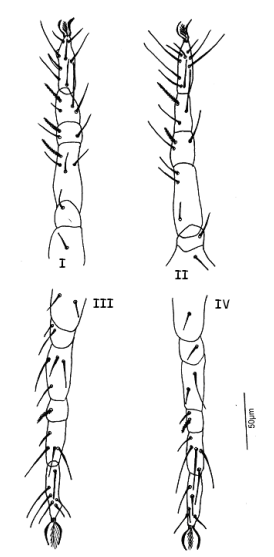

Fig. 1C. Eustigmaeus hooriaae n.sp. Legs I-IV 


\section{Etymology:}

This n.sp. named in the honors of author's sister name.

Male:

Unknown

Type:

Holotype female collected from Ameen Pur Bangla 20 miles away north from Faisalabad city from Triticum aestivum (straw husk) on 14-02-2005 (Bilal Saeed Khan). 12 paratype females were collected from the same locality. 6 paratypes collected from R.Y. Khan from leaf litter. All specimens were deposited in Acarology Research Laboratory, Department of Agri. Entomology, University of Agriculture, Faisalabad.

\section{Remarks:}

This new species can be separated from Eustigmaeus layallpuriensis on the basis of following points:

1. Palptarsus provided with 5 setae, triangular solenidion in this n.sp. while 4 setae without triangular solenidion in Eustigmaeus layallpuriensis.

2. Seta $l i 35 \mu \mathrm{m}$ longest in this n.sp. while be $67 \mu \mathrm{m}$ in Eustigmaeus layallpuriensis.

3. Seta $a, b, c$ and $c e 20 \mu \mathrm{m}$ equal with $l a$ length in this n.sp. while seta $b$ and le subequal in length in Eustigmaeus layallpuriensis.

4. Sternal shield provided with visible reticulations in this n.sp. while not visible in Eustigmaeus layallpuriensis.

5. 4 pairs of anogenital setae with striations on anogenital plate in this n.sp. while 3 in Eustigmaeus layallpuriensis.

6. Chaetotaxy leg I-IV differs remarkably in both species.

\section{KEY TO GENUS EUSTIGMAEUS FORM PUNJAB, PAKISTAN (Females)}

1. Solenidion present on palp tarsalpeg; propodosomal shield incompletely visible; setae $e$ \& le equal; tibia I with 4 setae........................hooriaae (n.sp)

Solenidion absent on palp tarsalpeg; propodosomal shield completely visible; $e$ \& $l e$ unequal; tibia I with 7 setae...............................................

2. Palptibia without setae; eyes absent; ventral gnathosoma with 3 pairs of setae; 2 pairs of anogenital setae. yussufii (Chaudhri)

Palptibia with more than 2 setae; eyes present; ventral gnathosoma with more than 3 pairs of setae; 3 pairs of anogenital setae.

...3

3. Palpgenu with 1 seta; palppeg larger than main claw; ventral idiosoma with 4 pairs of setae; more than 2 pairs of paragenital setae. hashmii (Chaudhri)

Palpgenu with 2 seta; palppeg equal with main claw; ventral idiosoma with more than 4 pairs of setae; 2 pairs of paragenital setae........ layallpuriensis (Chaudhri)

\section{ACKNOWLEDGEMENT}

I am obliged to Dr. Eddi Ueckermann, Dr. Fan and Dr. Salih Dogan for their help in stigmaeid literature and information.

\section{REFERENCES}

Berlese, A. (1910). Acari nuovi. Manipulus V. Redia, 6(2): 199-214.

Chaudhri, W. M., (1965). New mites of the genus Eustigmaeus. Acarologia, 7: 467-486.

Chaudhri, W. M. (1974). Taxonomic studies of the mites belonging to the families Tenuipalpidae, Tetranychidae, Tuckerellidae, Caligonellidae, Stigmaeidae and Phytoseiidae. Tech. Bull. No.1: 250 pp. 
Gerson, U. (1971a). Mites of the genus Ledermulleria (Prostigmata: Stigmaeidae) associated with mosses in Canada. Acarologia 13(2): 319-343.

Khanjani, M. \& Ueckermann, E. A. (2002). The Stigmaeid mite of Iran (Acari: Stigmaeidae). International Journal of Acarology, 28, 317-339.

Oudemans, A. C. (1923a). Acarologische aanteekeningen LXX. Entomologische Berichten, 6 (129): 138-144.

Oudemans, A. C. (1923b). Acarologische Anteekeningen. LXXI. Entomologie Berichten, Amsterdam, 6: 145-155.

Summers, F. M. and Price, D. W. (1961). New and redescribed species of Eustigmaeus from North America. Hilgardia, 31: 369-382.

Summers, F. M. (1957). American species of Ledermulleriopsis with a note on new synonymy in Neograthus (Acari: Stigmaeidae) Proc. Ent. Soc. Wash., 59 (2): 49-60.

Summers, F. M. (1957). Two mites of the genus Cheylostigmaeus including a new species from Point Barrow, Alaska. Pan. Pac. Ent., 33: 163-169pp.

Wood, T. G. (1973). Revision of stigmaeidae (Acari:Prostigmata) in the Berlese collection. Acarologia, 15:76-95.

Wood, T. G. (1966). Mites of the genus Eustigmaeus (Prostigmata: Stigmaeidae) from New Zealand, with records of one species from some Southern Pacific Islands. New Zealand J. Sci., 9(1): 84-102. 